\title{
METODE PEMBELAJARAN TAFSIR DI SEKOLAH BERBASIS ‘ULUM AL-QUR’AN
}

\author{
Agus Imam Kharomen \\ UIN Walisongo Semarang \\ E-mail: agusimamkharomen@walisongo.ac.id \\ https://doi.org/10.36052/andragogi.v8i2.179 \\ Diterima: 09 Oktober 2020 | Disetujui: 20 Desember 2020 | Dipublikasikan: 26 Desember 2020
}

\begin{abstract}
Abstrak
Tulisan ini merupakan respon atas minimnya rumusan metode pembelajaran tafsir di sekolah. Penelitian ini menunjukkan metode pembelajaran tafsir berbasis 'ulum al-Qur'an terdiri dari tiga aspek, yaitu landasan, materi dan metode pembelajaran. Landasan pembelajaran tafsir mengacu pada tiga hal: sesuai fungsi al-Qur'an, bertahap dan tidak memberatkan. Materi pembelajaran tafsir bisa menggunakan kisah-kisah dalam al-Qur'an, asbab al-nuzul dan tema pokok al-Qur'an. Adapun pada proses pembelajaran tafsir adalah menggunakan metode ijmali. Penelitian ini merupakan kajian kepustakaan (library research) dengan sumber data kitab dan buku 'ulum al-Qur'an Mabahits fi 'Ulum al-Qur'an karya Manna' al-Qathan, 'Ulum al-Qur'an karya Nuruddin 'Itr, Kaidah tafsir karya M. Quraish Shihab dan Membumikan Ulumul Qur'an karya Ahsin Sakho Muhammad serta hasil penelitian berupa jurnal dan lainnya dalam bidang pendidikan. Dalam prosesnya penelitian ini menggunakan metode deskriptif analitis dengan pendekatan content analysis dan interpretasi kontekstual.
\end{abstract}

Kata Kunci: Metode pembelajaran tafsir, 'Ulum al-Qur'an, Sekolah

\begin{abstract}
[LEARNING METHOD OF TAFSIR BASED ON 'ULUM AL-QUR'AN IN SCHOOL]. This paper is aimed to respond to the lack of formulation of tafsir learning methods at schools. This study shows that the learning method with the basis of Ulum al-Qur'an consists of three aspects, i.e. the foundation, learning material, and method. The foundation of tafsir learning comprises three elements; it must be based on the function of the Qur'an, gradual, and not burdensome. Then, the learning materials of tafsir can use the stories contained in the Qur'an, asbab al-nuzul (reason of revelation), and the main themes of the Qur'an. Meanwhile, the tafsir learning process uses the ijmali method. This is a librarybased study with data sources from books, especially 'Ulum al-Qur'an Mabahits fi 'Ulum al-Qur'an by Manna' al-Qathan, 'Ulum al-Qur'an by Nuruddin' Itr, Kaidah Tafsir by M. Quraish Shihab, and Membumikan Ulumul Qur'an by Ahsin Sakho Muhammad as well as research results in the form of journals and others in the field of education. In the process, this study uses a descriptive-analytical method with a content analysis approach and contextual interpretation.
\end{abstract}

Keywords: Tafsir learning methods, 'Ulum al-Qur'an, Schools 


\section{PENDAHULUAN}

A l-Qur'an merupakan salah satu materi pembelajaran di lembaga pendidikan agama Islam, baik sekolah, madrasah ataupun lembaga non formal seperti pondok pesantren dan madrasah diniyah.

Berdasarkan pengamatan yang telah dilakukan penulis di berbagai lembaga pendidikan, paling tidak dapat diketahui pembelajaran al-Qur'an yang dilakukan terdiri dari dua aspek, yakni aspek bacaan dan pemahaman.

Pada aspek pertama, proses pembelajaran berfokus pada teks-teks al-Qur'an, yakni pada tatacara dan tuntunan membaca al-Qur'an. Tujuan pembelajaran ini adalah agar para siswa, murid, dan santri dapat membaca al-Qur'an secara benar sesuai kaidah dalam ilmu tajwid.

Adapun aspek yang kedua dari al-Qur'an yang diajarkan di sekolah dan lembaga pendidikan Islam lainnya adalah aspek maknanya. Di sini para guru mentransformasikan pengetahuan tentang maknamakna yang dikandung ayat-ayat al-Qur'an. Tujuan pembelajaran ini adalah agar siswa atau murid bisa memahami, menghayati

dan mengimplementasikannya dalam kehidupan beragama dan sosial di masyarakat.

Kedua materi ini adalah keniscayaan yang tidak bisa ditawar, karena sebagai lembaga pendidikan Islam, mempunyai tanggung jawab mengantarkan para siswanya cakap dalam membaca dan memahami makna al-Qur'an.

Tetapi pada kenyatannya, pembelajaran bacatulis al-Qur'an di sekolah yang notabene Sekolah Islam lebih menjadi prioritas dibandingkan pembelajaran makna ayat-ayat al-Qur'an.

Hal tersebut terlihat dari jargon, program unggulan yang diusung sekolah-sekolah Islam dan metode baca tulis al-Qur'an yang sudah disediakan sedemikian rupa bahkan dijadikan semacam daya jual untuk menarik siswa baru.

Sejauh ini sangat banyak rumusan metode dalam mempelajari cara membaca al-Qur'an. Sebut saja misalnya metode iqro', qiro'ati, al-barqi, Yanbu'a (Anggranti, 2016: 108) Tidak seperti metode pembelajaran tafsir al-Qur'an yang lebih menerima apa adanya dengan mengacu pada buku yang disediakan oleh lembaga terkait.

Selain itu, sampai saat ini kajian tafsir al-Qur'an lebih banyak dilakukan oleh lembaga-lembaga pendidikan khusus seperti perguruan tinggi dan pondok pesantren, sehingga memberikan kesan bahwa mempelajari tafsir al-Qur'an hanya untuk para orang dewasa. Akibatnya pembelajaran alQur'an yang menyentuh tataran maknanya (substantif) tidak dapat dijadikan tradisi sejak dini di kalangan siswa baik di tingkatan dasar ataupun menengah (Taufiq, 2011: 124)

Bahkan dari beberapa model pembelajaran tafsir yang ada sekarang ini, hanya dapat dikonsumsi oleh orang dewasa dari kalangan mahasiswa, dosen, ataupun cendekiawan dan belum menyentuh dunia siswa atau anak-anak (Adib, 2018: 465)

Oleh karena itu, melalui artikel ini penulis mencoba menawarkan metode pembelajaran tafsir al-Qur'an berbasis pada ulum al-Qur'an. Metode yang dimaksud di sini mencakup landasan, materi, dan cara pembelajaran tafsir.

\section{METODE PENELITIAN}

Kajian ini merupakan studi kepustakaan (library research) dengan metode deskriptif-analitis. Artinya data-data yang telah dihimpun digambarkan secara apa adanya untuk kemudian dianalisis. Dalam proses analisis menggunakan pendekatan content analisis dan interpretasi kontekstual, yakni memahami dan mengungkapkan makna yang terkandung dalam materi ulum al-Qur'an kemudian menariknya dalam konteks pendidikan khususnya pembelajaran tafsir al-Qur'an.

Sumber data penelitian ini adalah kitab dan buku 'ulum al-Qur'an yaitu Mabahits fi 'Ulum alQur'an karya Manna' al-Qathan, 'Ulum al-Qur'an karya Nuruddin 'Itr, Kaidah tafsir karya M. Quraish Shihab, Membumikan Ulumul Qur'an karya Ahsin Sakho Muhammad dan hasil penelitian berupa jurnal atau lainnya dalam bidang pendidikan yang mempunyai relevansi dengan pembahasan penelitian ini.

Langkah-langkah analisis yang dilakukan terdiri dari tiga tahap, pertama reduksi data, yakni dari berbagai sumber yang telah dikumpulkan, penulis pilah dan sesuaikan dengan pembahasan penelitian ini. Kedua, penyajian data, dari hasil pemilahan tadi penulis susun dalam bentuk narasi yang tersusun dalam sub-sub bab. Terakhir adalah penyimpulan data, merupakan narasi singkat dari hasil analisis yang telah dilakukan. 


\section{TEMUAN DAN PEMBAHASAN}

Berikut ini penjelasan tentang istilah teknis dalam penelitian ini. Pertama adalah metode, yang berarti jalan atau cara yang harus dilakukan untuk sampai kepada tujuan. (Abdul Majid, 2013: 13) Sedangkan pembelajaran menurut Undang-undang Republik Indonesia Nomor 20 tahun 2003 tentang Sistem Pendidikan Nasional, yakni pembelajaran adalah proses interaksi pendidik dan peserta didik dan sumber belajar yang berlangsung dalam suatu lingkungan belajar (Republik Indonesia, 2003: 6), sedangkan pengetian tafsir secara singkat adalah penjelasan tentang maksud firman-firman Allah sesuai kemampuan manusia. (Quraish, 2013: 9). 'Ulum al-Qur'an berarti pembahasan-pembahasan yang berkaitan dengan al-Qur'an dalam berbagai aspeknya, mulai dari sejarah turun dan pembukuan al-Qur'an, penafsiran, kemu'jizatan al-Qur'an, nasikh mansukh dan hal-hal lain yang berkaitan dengan al-Qur'an (Ahsin, 2019: 15)

Berdasarkan penjelasan di atas dapat disimpulkan bahwa arah penelitian ini adalah membahas cara interaksi pendidik dan peserta didik dalam mempelajari tafsir dengan berpijak pada konsep-konsep ‘ulum al-Qur'an.

Kajian tentang metode pembelajaran tafsir, tidak sebanyak kajian metode pembelajaran bacatulis al-Qur'an. Meskipun demikian ada beberapa penelitian yang sudah membahasnya.

Pertama laporan pengabdian berbasis penelitian yang dilakukan Hadi Nur Taufiq. la menawarkan metode pembelajaran tafsir bagi guru TPQ dengan menggunakan metode tafsir tematik. Meskipun sama dengan penelitian penulis dari sisi temanya, tapi tawaran yang dihasilkan berbeda, karena penulis mencoba menawarkan metode pembelajaran tafsir berbasis ‘ulum al-Qur'an.

Kedua, penelitian Ainal Mardhiah yang menyoroti pembelajaran tahfizh, tafsir, terjemah, asbab al-nuzul dan munasabah. la menawarkan langkah-langkah teknis dalam setiap pembelajaran materi tersebut. Di sinilah perbedaan dengan tulisan penulis yang lebih fokus pada pembelajaran tafsir di sekolah yang tidak hanya langkah-langkahnya, tetapi juga dasar pemikiran dan materi tafsir yang diajarkannya.

Terakhir adalah penelitian Shohibul Adib yang merupakan kajian terhadap buku tafsir al-Qur'an untuk anak karya Afif Muhammad. Meskipun pembahasannya berkaitan dengan penelitian penulis, tetapi Shohibul Adib hanya fokus menganalisis buku tersebut.

Berikut ini adalah metode pembelajaran tafsir berbasis 'ulum al-Qur'an yang ditawarkan penulis, dalam hal ini terdiri dari tiga hal. Yakni (1) landasan pembelajaran tafsir, (2) materi pembelajaran tafsir, (3) cara pembelajaran tafsir.

\section{A. Landasan pembelajaran tafsir}

Menjadi penting bagi pendidik yang melaksanakan pembelajaran tafsir untuk mengetahui landasan yang akan dijadikan pijakan dan pemikiran selama melaksanakan proses pembelajaran. Dalam hal ini ada tiga landasan, yang akan dijelaskan berikut ini:

\section{Sesuai fungsi al-Qur'an}

Al-Qur'an adalah kitab suci umat muslim yang berfungsi sebagai huda (petunjuk) baik secara khusus bagi orang bertaqwa ataupun manusia pada umumnya seperti disebutkan dalam surah alBaqarah ayat 2 dan 185 berikut ini:

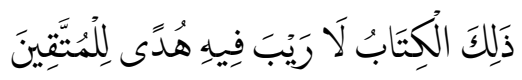

$$
\text { (البقرة: ) }
$$

Artinya: Itulah al-Kitab (al-Qur'an), tidak ada keraguan padanya; petunjuk bagi orang-orang yang bertaqwa (QS. al-Baqarah: 2)

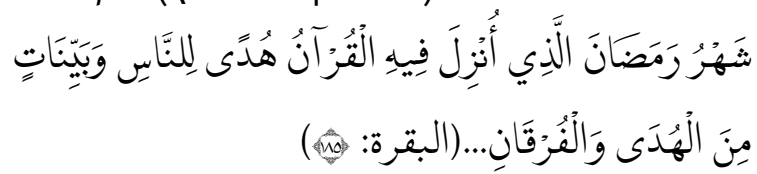

Artinya: Bulan Ramadhan yang di dalamnya diturunkan al-Qur'an sebagai petunjuk bagi manusia dan penjelasan mengenai petunjuk-petunjuk itu serta pembeda antara yang haq dan yang batil... (QS. al-Baqarah: 185)

Kedua ayat ini menunjukkan fungsi alQur'an sebagai petunjuk, bahkan tidak hanya pertunjuk, tetapi juga penjelasan dan pembeda bagi manusia antara kebenaran dan kebatilan.

Dalam proses pembelajaran tafsir hendaknya seorang pendidik memfokuskan pada menjelaskan petunjuk yang terdapat dalam ayat yang dibahas, bukan pada hafalan terjemah kosakata ayat. Ketika peserta didik diarahkan untuk menghafal dan mengucapkan kembali kosakata ayat beserta 
terjemahannya seperti yang terlihat dari buku-buku pelajaran al-Qur'an Hadis siswa yang diterbitkan oleh Kementerian Agama antara lain yang ditulis oleh Niswatul Khoiriyah (2019), Abdul Jalil (2019) dan Nawawi Syahid, Mustam, Abdul Hamid (2014).

Hal di atas menjadikan peserta didik tidak fokus pada petunjuk yang terkandung dari ayat yang dibahas, karena beban peserta didik bertambah, tidak hanya berusaha memahami makna ayat-ayat al-Qur'an, tetapi membaca al-Qur'an sesuai tajwid dan menghafalkannya. Menurut penulis materi tajwid dan hafalan ayat dapat dimuat pada mata pelajaran yang lain, misalnya BTQ (Baca Tulis alQur'an) dan Tahsin Tahfizh.

Memfokuskan pada pengungkapan petunjuk yang terkandung dalam ayat yang dibahas akan lebih memudahkan peserta didik untuk memahami dan mengingat maksud ayat al-Qur'an yang dikaji. Dengan demikian akan mengantarkannya pada mengimplementasikan dalam kehidupan seharihari.

\section{Bertahap}

Dalam 'ulum al-Qur'an, ada bab khusus yang membahas sejarah turunnya al-Qur'an, atau disebut asbab al-nuzul. Dalam bab ini dijelaskan bahwa proses turunnya al-Qur'an terdiri dari dua, pertama al-Qur'an diturunkan secara keseluruhan dari lauh mahfuzh ke bait al-'izzah di langit dunia. Kedua, turun secara berangsur-angsur, sedikit demi sedikit dari bait al-'izzah dibawa malaikat Jibril kepada Nabi Muhammad Saw selama kurang lebih 23 tahun. (alQathan, 2000: 101)

Turunnya al-Qur'an secara bertahap mempunyai tujuan dan hikmah. Di antaranya meneguhkan hati Nabi Saw, memudahkan untuk dihafal dan dipahami, merespon problem yang terjadi dan bertahap dalam proses penetapan hukum. (alQathan, 2000: 1015-107)

Nuruddin 'Itr menyebutkan, proses turunnya alQur'an secara bertahap mengajarkan pada kita bahwa dalam melaksanakan pendidikan perlu tahapan-tahapan, berhati-hati mulai dari satu langkah, ke langkah selanjutnya. ('Itr, 1996: 33)

Pemaknaan yang diungkapkan 'Itr di atas sesuai dengan sifat dari sebuah pendidikan yakni sebagai sebuah proses. Maka dalam konteks pembelajaran tafsir juga harus dipahami sebagai suatu proses yang bertahap dan berkelanjutan, bukan instan.
Demikian juga dengan tafsir, dengan mengkontekstualisasikan penjelasan 'Itr, maka pembelajaran tafsir juga harus dilakukan secara bertahap, mulai dari sekolah dasar, menengah, menengah atas sampai perguruan tinggi, yang pada tiap jenjangnya perlu dirumuskan sesuai karakter dari subyek (peserta didik).

Materi tafsir yang bisa diberikan kepada siswa, maka dapat diberikan terlebih dahulu. Adapun materi yang tafsir yang membutuhkan penalaran lebih dan mendalam disiapkan untuk diberikan ketika sudah di perguruan tinggi.

Dengan demikian, bertahap adalah landasan penting dalam pembelajaran tafsir, mengingat cakupan tafsir sangat luas, tema yang tekandung di dalamnya pun sangat beragam, maka seorang pendidik perlu menyiapkan tahapan-tahapan tertentu sesuai dengan kebutuhan siswa. Terutama dari segi kontennya. Sebagaimana nanti akan dibahas pada bagian materi pembelajaran tafsir.

Terkait hal ini al-Qathan mengeaskan bahwa prinsip bertahap dalam mengkaji al-Qur'an akan lebih membantu dalam menghafal, memahami, merenungkan dan mengamalkan petunjuk alQur'an. (al-Qathan, 2000: 112)

\section{Tidak memberatkan}

Landasan ketiga adalah tidak memberatkan para peserta didik. Landasan ini juga merupakan kontekstualisasi dari hikmah turunnya al-Qur'an secara bertahap yang salah satu tujuannya agar tidak memberatkan umat dalam menerapkan ajaran agama.

Demikian juga para peserta didik, ketika mereka diberikan materi tafsir yang tidak sesuai dengan usia dan kecenderungan dunianya, maka akan berat bagi mereka untuk memahami petunjuk al-Qur'an yang terdapat dalam ayat yang dibahas.

$\mathrm{Di}$ sini peran penting pendidik dalam memilihkan materi tafsir yang sesuai dengan kondisi peserta didik. Sehingga tafsir bisa juga dipelajari oleh siswa, tidak hanya para mahasiswa dan pakar.

Tidak hanya terkait materi yang diajarkan, tetapi juga terkait metode pembelajaran, yang jika tidak sesuai dengan kondisi peserta didik akan menjadikan mereka merasakan berat dalam menjalani proses pembelajaran.

Menurut Rohman, hal tersebut dikarenakan seseorang yang tidak memiliki kesadaran terhadap pekerjaannya, atau belum memahami manfaat dan 
kegunaanya, akan sering merasakan berat. Kondisi inilah yang sering dijumpai di kehidupan anak-anak. (Rohman, 2018: 78)

Jika merujuk penjelasan al-Qathan diketahui ia menegaskan bahwa prinsip tidak memberatkan adalah landasan dalam pembelajaran secara umum, tidak hanya dalam bidang tafsir. Al-Qathan menambahkan dengan menjadikan pelajaran itu mudah maka kita telah menjaga keseimbangan emosional para peserta didik, menjaga perkembangan kemampuan mereka, baik akal, jiwa dan badan untuk bisa tumbuh secara sehat dan baik (al-Qathan, 2000: 112)

Demikian tiga landasan utama yang ketiganya harus selalu menjadi dasar para pendidik dalam melaksanakan pembelajaran tafsir, sehingga proses pembelajaran akan dilalui dengan mudah oleh peserta didik, dan dapat memberikan dampak positif terutama dalam penghayatan dan pengamalan nilai-nilai yang dikandung dalam ayatayat al-Qur'an yang dipelajari. Selanjutnya akan dibahas materi tafsir yang bisa dijadikan bahan kajian bagi para peserta didik di sekolah.

\section{B. Materi Pembelajaran Tafsir}

Pada pembahasan sebelumnya telah disebutkan bahwa materi tafsir sangat beragam dan mempunyai segmennya masing-masing, ada yang sesuai diberikan kepada anak-anak di sekolah, dan ada yang sesuai bagi mereka di perguruan tinggi.

Oleh karena itu, merumuskan materi tafsir yang akan diajarkan di sekolah juga menjadi penting dalam mencapai keberhasilan pembelajaran tafsir. Menurut penulis, berdasarkan kajian-kajian yang terdapat dalam 'ulum al-Qur'an, ada tiga materi tafsir yang dapat diajarkan kepada peserta didik di sekolah. Yakni:

\section{Kisah-kisah al-Qur'an}

Dalam kajian al-Qur'an kisah disebut dengan qashash, yang secara bahasa berarti menelusuri jejak. Adapun secara istilah berarti berita yang terdapat di dalam al-Qur'an, yang mencakup berita tentang umat-umat terdahulu, para nabi dan peristiwa dan kejadian yang mencakup manusia, negara ataupun lainnya. (al-Qathan, 2000: 300)

Dalam al-Qur'an terdapat tiga macam kisah, yakni kisah para nabi, kisah yang berkaitan dengan peristiwa yang terjadi dan orang-orang selain nabi dan kisah yang terjadi pada masa Rasulullah Saw. (ash-Shiddieqy, 2002: 180)

Berdasarkan penjelasan al-Qathan dan ashShiddieqy di atas diketahu bahwa kisah-kisah yang terdapat dalam al-Quran sangat beragam.

Menurut Quraish Shihab, dari ragam kisah yang terdapat di al-Qur'an dapat dipahami beberapa hal sebagai berikut, yang pertama jika kisah itu berkaitan dengan tokoh/sosok manusia, maka alQur'an menampilkan sisinya yang dapat diteladani. Jika yang ditampilkan sisi kelemahannya atau keburukannya maka di akhir cerita yang ditonjolkan adalah kesadaran dari sosok tersebut atau dampak buruk yang dialaminya. Kedua jika yang disampaikan adalah sebuah masyarakat maka yang ditonjolkan adalah sebab jatuh bangunnya masyarakat tersebut. (Quraish, 2013: 321-322)

Salah satu karakteristik kisah al-Qur'an, yang membedakannya dengan kisah selain al-Qur'an adalah bahwa kisah-kisah yang terdapat dalam alQur'an tidak disampaikan secara utuh, tetapi hanya episode-episode tertentu, dan terkadang tidak disebutkan secara jelas tempat, waktu dan pelakunya. Hal ini dikarenakan agar menjadi pelajaran untuk semua pihak, kapan dan dimanapun. Demikian al-Sya'rawi yang dikutip oleh Quraish Shihab. (Quraish, 2013: 322-323)

Menambahkan penjelasan Quraish Shihab, menurut penulis alasan tidak disebutkannya episode kisah secara lengkap karena tujuan utama dari alQur'an bukanlah bercerita, tetapi menyampaikan petunjuk kebaikan kepada umat, cerita yang disampaikan hanya sebagai cara atau media penyampaiannya. Sehingga umat dapat langsung mengetahui pelajaran dari kisah tersebut tanpa harus menyelesaikan cerita itu.

Menurut ash-Shiddieqy di antara tujuan adanya kisah dalam al-Qur'an adalah menjelaskan dasardasar dakwah agama Allah dan menerangkan pokokpokok syariat yang disampaikan para rasul, mengokohkan hati Rasul dan umat muslim, mengabadikan usaha-usaha para nabi dan menegaskan kebenaran para nabi-nabi terdahulu, serta menarik perhatian umat Islam yang diberikan pelajaran. (ash-Shiddieqy, 2002: 181)

Kisah-kisah yang terdapat dalam al-Qur'an dapat dijadikan materi pembelajaran tafsir di sekolah, karena melalui kisah para siswa/peserta didik akan lebih mudah menerimanya sesuai dengan kecenderungan manusia, pesan-pesan pendidikan 
yang ada di dalamnya akan mudah diterima tanpa disadari dan memerlukan penalaran yang panjang. Berbeda dengan penjelasan narasi bukan kisah, pasti penerimaannya akan lebih sulit dan cenderung membosankan. Demikian disebutkan dalam Mabahits fi 'Ulum al-Qur'an (al-Qathan, 2000: 305)

Selain itu, jika dikaitkan dengan anak-anak, cerita atau kisah mempunyai daya tarik dan kekuatan khusus untuk menarik simpati mereka, perasaan mereka menjadi aktif, menjadi penghibur sekaligus nasihat terutama dapat membentuk kepribadian anak. Melalui ceirta anak dapat memahami kejadian di sekelilingnya dan mampu mengingat apa yang telah disampaikan kepada mereka. (Fajrien, 2009: 7)

Agus Fatah, seperti yang dikutip oleh Fajrien menjelaskan banyak manfaat kisah bagi anak atau peserta didik, di antaranya menstimulasi rasa ingin tahu dan mengembangkan imajinasi, meningkatkan konsentrasi, kecerdasan, serta kemampuan berkomunikasi dan berbahasa (Fajrien, 2009: 38)

Penjelasan al-Qathan dan Fajrien menunjukkan bahwa materi kisah dalam al-Qur'an merupakan pilihan yang sesuai dalam pembelajaran tafsir di sekolah. Terlebih lagi bagi peserta didik pada sekolah dasar, karena pada umur 7-8 tahun adalah kecenderungan mereka menyukai kisah rakyat, para nabi, dan lain sebagainya. (Fajrien, 2009: 59).

Seorang pendidik dapat memberikan pelajaran kisah al-Qur'an sesuai dengan daya nalar para peserta didik di tiap tingkatannya. Seperti keberhasilan yang luar biasa dari kumpulan kisahkisah keagamaan karya Sayyid Qutub dan al-Sahar yang telah memberikan manfaat kepada para anakanak/peserta didik (al-Qathan, 2000: 305)

Pendapat al-Qathan ini menjadi petunjuk bahwa untuk sekolah dasar bisa diberikan tafsir yang berupa kisah-kisah para nabi dan tokoh-tokoh dengan karakter yang baik yang ada di al-Qur'an. Bahkan tidak menutup kemungkinan juga ayat-ayat yang berisi kejadian yang berkaitan dengan binatang, seperti pada surat al-fil, al-naml, dan sebagainya.

Adapun bagi peserta didik di tingkat menengah dan atas yang sudah mulai melakukan penalaran dan penghayatan yang lebih tinggi, maka dapat diberikan materi kisah-kisah kejadian masa lalu atau masa Nabi, dan para tokoh dengan karakter buruk seperti orang yang menghardik anak yatim dalam surah al-ma'un, orang yang mengurangi timbangan dalam surah al-muthafifin dan lain sebagainya. Karena mereka sudah dapat membedakan mana muatan kisah yang dapat diteladani dan tidak.

Jadi tetap memberikan pelajaran tafsir al-Qur'an hanya saja ayat-ayat yang dipilih adalah yang berkaitan dengan kisah-kisah al-Qur'an. Dengan kata lain memahami ayat-ayat al-Qur'an yang mengandung kisah. Dengan tujuan akhir para peserta didik dapat mengambil pelajaran/ibrah dari setiap kisah al-Qur'an. Sebagaimana dijelaskan dalam surah Yusuf ayat 111 berikut ini:

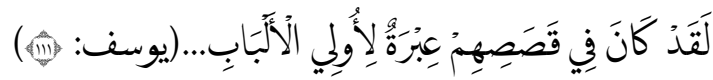

Artinya: Demi (Allah) sungguh pada kisah-kisah mereka terdapat pelajaran bagi orang-orang yang berakal bersih, murni dan cerah. (QS. Yusuf: 111)

Pelajaran yang terkandung dalam kisah alQur'an pun beragam seperti yang telah dijelaskan Quriash Shihab dan al-Qathan, ada pelajaran yang berkaitan dengan akidah, etika/akhlak, prinsipprinsip kehidupan, dan lain sebagainya. Sehingga menurut penulis pendidik bisa memilihkan ayat tentang kisah yang sesuai dengan pelajaran apa yang akan diberikan kepada peserta didik.

\section{Asbab al-Nuzul}

Tema pembelajaran tafsir selanjutnya adalah asbab al-nuzul. Dalam kajian 'ulum al-Qur'an asbab al-nuzul berarti peristiwa atau kejadian khusus yang melatarbelakangi turunnya ayat al-Qur'an. Dengan kata lain peristiwa yang berkaitan dengan turunnya ayat. Pengetahuan tentang asbab al-nuzul sangat penting dalam memahami makna ayat al-Qur'an secara benar dan tepat. ('Itr, 1996: 46-47)

Dalam pengertian yang dijelaskan 'Itr di atas, maka tidak semua ayat memiliki asbab al-nuzul, karena ada ayat yang diturunkan tanpa ada sebab atau peristiwa khusus.

Asbab al-nuzul berbentuk cerita, dan dapat dijadikan alternatif dalam pembelajaran tafsir. Pada pembahasan sebelumnya telah dijelaskan bahwa pelajaran tafsir bisa dengan memilih ayat-ayat yang termasuk kategori kisah, maka di sini yang ditawarkan adalah pendidik bisa memilih ayat-ayat al-Qur'an yang memiliki asbab al-nuzul.

Adapun untuk mengetahuinya, pendidik bisa merujuk pada kitab-kitab yang secara khusus menghimpun asbab al-nuzul. Misalnya kitab Lubab al-Nuqul fi Asbab al-Nuzul karya al-Suyuthi dan Asbab al-Nuzul karya al-Wahidi. Dari kitab itu juga 
pendidik bisa memilihkan ayat dan asbab al-nuzul nya yang sesuai dengan jenjang para peserta didik.

Tujuan materi tafsir berupa ayat-ayat yang memiliki asbab al-nuzul ini adalah agar peserta didik dapat lebih menerima dan tertarik memahami ayat karena ada cerita yang berkaitan dengan ayat tersebut.

Menurut penulis, materi asbab al-nuzul dapat menjadi penunjang dalam rangka lebih memudahkan peserta didik di sekolah untuk memahami makna yang terkandung dari ayat-ayat al-Qur'an.

\section{Tema pokok al-Qur'an}

Alternatif ketiga adalah memberikan materi tafsir dengan mempertimbangkan tema pokok dalam al-Qur'an. Dalam pembahasan ulum al-Qur'an dikenal pembagian tema-tema utama yang terdapat dalam al-Qur'an.

Misalnya penjelasan Mahmud Syaltut yang dikutip Moh. Nor Ichwan, bahwa al-Qur'an mengandung lima tema atau pembahasan utama, yakni akidah, akhlak atau budi pekerti, peringatan dan ancaman petunjuk dan bimbingan untuk menyelidiki, mentadabburi rahasia-rahasia alam semesta, dan hukum-hukum baik ibadah ataupun sosial. (Ichwan, 2005: 44-45)

Dengan mengetahui tema pokok al-Qur'an, pendidik bisa memilihkan tema-tema yang sesuai dengan peserta didik sesuai jenjangnya. Untuk membantu penelusuran tema-tema pokok tersebut, penulis bisa menggunakan kamus atau indeks alQur'an baik perkata ataupun tematik. Kamus perkata misalnya al-Mu'jam al-Mufahras li Alfazh al-Qur'an karya Fuad Abd al-Baqi dan Fath al-Rahman li Thalib Ayat al-Qur'an karya Faid Alllah al-Hasani alMaqdisi. Adapun yang tematik misalnya al-Mu'jam al-Maudhu'i li Ayat al-Qur'an al-Karim karya Shubhi 'Abd al-Rauf 'Ashar.

Misalnya bagi peserta didik di tingkat dasar, maka bisa dipilhkan ayat-ayat tentang akidah dan akhlak. Kemudian di tingkatan menengah mulai bisa diajarkan ayat-ayat tentang hukum baik ibadah dan sosial, sedangkan peserta didik menengah atas bisa mulai dikenalkan ayat-ayat yang berisi petunjuk untuk mentadabburi alam dan ayat-ayat tentang janji dan ancaman. Dengan demikian diharapkan peserta didik di tiap tingkatnya dapat menerima pembelajaran tafsir dengan mudah dan sistematis.
Urutan pelajaran berdasarkan tema juga tercermin dari proses turunnya ayat al-Qur'an. Seperti diriwayatkan oleh al-Bukhari yang bersumber dari ‘Aisyah. Beliau menjelaskan pertama kali ayat yang diturunkan adalah surah al-mufashal yakni surat-surat pendek, yang di dalamnya disebutkan tentang surga, neraka, kemudian setelah umat telah kuat memeluk Islam, barulah diturunkan ayat-ayat tentang halal haram, larangan minum arak dan zina. Jika ayat-ayat tentang laranganlarangan diturunkan lebih awal maka pasti mereka akan menolaknya, kita tidak anak meninggalkan minum arak dan lainnya. (al-Bukhari, 2001: 85)

Berdasarkan riwayat ini, ayat akidah turun lebih dahulu sebelum ayat-ayat hukum.

Meskipun demikian, dalam konteks pembelajaran tafsir khususnya tema akidah, ada beberapa hal yang perlu diperhatikan oleh pendidik. Pertama ketika membahas tentang pahala dan siksa, surga dan neraka maka haruslah dijelaskan secara berimbang, jangan sampai ada kesan bahwa agama ini, khususnya Allah mengerikan atau kejam.

Dengan kata lain hendaknya pendidik tidak berlebihan membahas tentang neraka dan siksa Allah, sebaliknya perlu menekankan aspek rahman dan rahimnya Allah, bahwa sekalipun Allah memberikan siksa, tapi rahmat Allah kepada hambanya lebih besar sebagaimana disebutkan dalam hadits qudsi bahwa rahmatku mengalahkan murkaku. (al-Bukhari, 2001: 106)

Berdasarkan hadits Nabi yang diriwayatkan alBukhari di atas menunjukkan bahwa menanamkan pemahaman kepada peserta didik akan sifat kasih sayang Allah, bahwa Allah adalah yang merawat manusia, Allah menerima taubat hambanya dan halhal lain yang berdampak positif bagi pertumbuhan anak adalah hal sangat penting untuk diterapkan dalam membahas tema akidah.

Dengan demikian diharapkan kelak peserta didik akan tumbuh menjadi pribadi yang taat kepada Allah dan agama dengan didasari cinta dan rasa syukur, bukan karena ketakutan kepada Allah dan siksanya.

Demikian tiga materi dalam pembelajaran tafsir. Dalam praktiknya ketiga materi tersebut dapat dikombinasikan. Misalnya memilih ayat dengan tema pokok akidah yang yang memiliki asbab al-nuzul dan mengandung kisah di dalamnya. Di sinilah peran dan kreatifitas pendidik akan sangat menunjang keberhasilan pembelajaran tafsir. 


\section{Metode pembelajaran tafsir}

Selain landasan dan materi pembelajaran, kedudukan metode juga sangat penting dalam mencapai keberhasilan proses pendidikan. Oleh karena itu, perlu merumuskan metode yang sesuai dengan pembelajaran tafsir di sekolah.

Dalam 'ulum al-Qur'an dikenal 4 metode penyajian tafsir, yakni tahlili, muqaran, ijmali dan Maudhu'i. (Quraish, 2013: 378) Tahlili adalah proses penyajian tafsir sesuai urutan sistematika mushaf dengan mengungkapkan berbagai aspek disiplin ilmu yang terkandung di dalam ayat yang dikaji, mencakup makna bahasa, qira'at, gramatikal, perbedaan pendapat para mufasir dan lain sebagainya. Sedangkan ijmali meskipun penyajiannya mengikuti sistematika mushaf, tetapi uraiannya lebih singkat, memfokuskan makna global dari ayat yang dikaji dan informasi penting lainnya secara singkat, seperti penyebutan asbab al-nuzul. (Quraish, 2013: 378-381)

Adapun muqaran lebih pada perbandingan penafsiran antar ayat, tidak terpaku pada sistematika mushaf al-Qur'an. Penyajian secara maudhu'i adalah menyajikan makna ayat al-Qur'an dalam bingkai tema tertentu. Dengan menentukan suatu tema kemudian mengkajinya berdasarkan ayat-ayat yang berkaitan dengan tema tersebut. (Quraish, 2013: 382-385)

Dengan mengacu penjelasan Quraish Shihab di atas dan pengamatan penulis terhadap hasil penafsiran dengan menggunakan keempat metode tersebut, penulis memilih metode ijmali (global) sebagai alat yang dipakai dalam pembelajaran tafsir. Hal ini didasari pada pertimbangan peserta didik dan fungsi al-Qur'an dalam pembelajaran tafsir.

Menurut penulis, perserta didik di sekolah adalah individu yang baru belajar tafsir, sehingga akan merasa berat dan kesulitan jika harus mengkaji makna al-Qur'an secara detail seperti metode tahlili, ataupun membandingkan antar penafsiran ayat seperti metode muqaran. Metode maudhu'i pun jika harus diterapkan di sekolah akan memberatkan peserta didik, karena sebagai pemula mereka harus memahami penjelasan ayat terkait segala aspek dari tema yang dikaji.

Adapun dari aspek tujuan al-Qur'an yang telah disebutkan (sebagai petunjuk), maka tujuan pembelajaran tafsir bagi peserta didik di sekolah difokuskan pada upaya mengungkapkan makna yang mudah dan ringkas berupa petunjuk atau pelajaran bagi peserta didik, bukan untuk tujuan pendalaman dan kajian akademik seperti di perguruan tinggi yang biasa menggunakan metode tahlili, maudhu'i maupun muqaran.

Pada praktiknya pendidik bisa mulai dengan membacakan teks ayat dan terjemahannya, kemudian mengajak para peserta didik untuk membacanya kembali. Setelah itu pendidik menjelaskan kandungan makna secara singkat dengan memfokuskan pada poin-poin yang dapat dijadikan pelajaran ataupun tuntunan bagi peserta didik. Pendidik juga dapat memanfaatkan berbagai media pembelajaran yang sesuai dengan materi tafsir yang sedang dibahas.

\section{PENUTUP}

\section{Simpulan}

Berdasarkan kajian atas buku 'Ulum Qur'an karya Manna' al-Qathan, 'Ulum al-Qur'an karya Nuruddin 'Itr, Kaidah tafsir karya M. Quraish Shihab dan Membumikan Ulumul Qur'an karya Ahsin Sakho Muhammad menggunakan pendekatan content analysis dan interpretasi kontekstual dapat penulis simpulkan bahwa Metode pembelajaran tafsir berbasis 'ulum al-Quran terdiri dari tiga aspek, yakni landasan, materi dan metode pembelajaran. Landasan pembelajaran tafsir mengacu kesesuaian dengan fungsi al-Qur'an, bertahap dan tidak memberatkan peserta didik. Sedangkan materi pembelajaran tafsir bisa menggunakan kisah-kisah dalam al-Qur'an, asbab al-nuzul dan tema pokok alQur'an. Adapun pada proses pembelajaran tafsir dapat menggunakan metode ijmali.

\section{Rekomendasi}

Hasil penelitian ini diharapkan dapat menjadi pertimbangan para pendidik dalam proses pelaksanaan pembelajaran tafsir di sekolah. Selain itu, bagi pemangku kebijakan dapat dijadikan bahan awal penyusunan panduan yang lebih komprehensif terkait pembelajaran tafsir di sekolah. 


\section{DAFTAR PUSTAKA}

Adib, Shohibul. (2018). Metode tafsir al-Qur'an untuk Anak Didik: Studi Buku tafsir al-Qur'an karya Afif Muhammad, Al-Riwayah Jurnal Kependidikan, 10 (2), 463-499.

Al-Bukhari, Abi ‘Abdillah Muhammad bin Sulaiman. (1980). Al-Jami' al-Shahih. Al-Mathba'ah al-Salafiyah.

Anggranti, Wiwik. (2016). Penerapan Metode Pembelajaran Baca Tulis al-Qur'an (Studi Deskripstif-Analitik di SMP Negeri 2 Tenggarong). Jurnal Intelegensia, 5 (1), 106-119.

ash-Shiddieqy, Muhammad Hasbi, 2002, Sejarah dan Pengantar IImu al-Qur'an dan Tafsir, Semarang: Pustaka Rizki Putra.

Fajrien, Dwika Novriyanti. (2009). Bimbingan Pembentukan Kepribadian Anak Melalui Kisah-Kisah Islami pada Siswa-Siswi SD Islam Sabilina Cibubur. Skripsi.

Ichwan, Moh. Nor. (2005). Belajar Al-Qur'an, Semarang: RaSAlL.

'Itr, Muhammad Nuruddin. (1996). 'Ulum al-Qur'an al-Karim, Damaskus: Maktabah al-Shabah.

Kementerian Agama Republik Indonesia. (2014). Buku Siswa Al-Qur'an Hadis Pendekatan Saintifik Kurikulum 2013 Madrasah Ibtidaiyah, Jakarta: Kementerian Agama Republik Indonesia.

Kementerian Agama Republik Indonesia. (2019). Buku Siswa Al-Qur'an Hadis Kelas IX Madrasah Tsanawiyah, Jakarta: Kementerian Agama Republik Indonesia.

Kementerian Agama Republik Indonesia. (2019). Buku Siswa Al-Qur'an Hadis Kelas XII Madrasah Aliyah, Jakarta: Kementerian Agama Republik Indonesia.

Majid, Abdul. (2013). Strategi Pembelajaran. Bandung: PT. Remaja Rosyda Karya.

Mardhiah, Ainal. (2013). Reorentasi Metodologi Pembelajaran Tafsir di Madrasah dan Pesantren. Jurnal Ilmiah DIDAKTIKA, 8 (2), 283-295.

Muhammad, Ahsin Sakho. (2019). Membumikan Ulumul Qur'an. Jakarta: Qaf Media.

Al-Qathan, Manna'. (2000). Mabahits fi 'Ulum al-Qur'an, Kairo: Maktabah Wahbah.

Republik Indonesia. (2003). Undang-undang Republik Indonesia Nomor 20 tahun 2003 tentang Sistem Pendidikan Nasional.

Rohman, Fatkhur. (2018). Peran Pendidikan dalam Pembinaan Disiplin Siswa di Sekolah / Madrasah. Ihya' al'arabiyah, 4 (1), 72-94.

Shihab, Quraish. (2013). Kaidah tafsir. Tangerang Selatan: Lentera Hati.

Taufiq, Hadi Nur. (2011). Pembelajaran al-Qur'an melalui Pendekatan Metode Tafsir Tematik bagi Guru TPQ di Kota Malang. Progresiva, 5 (1), 123-130.

Tea, T. (2009). Inspiring Teaching: Mendidik Penuh Inspirasi. Jakarta: Gema Insani. 